Журнал «Герспективитаінноваціїнауки»

(Серія«Гедагогіка»), Серія«ГТихологія», Серія «Медицина»

№5(5) 2021

УДК 159.9

https://doi.org/10.52058/2786-4952 -2021-5(5)-792-802

Мілорадова Наталія Едуардівна доктор психологічних наук, доцент, професор кафедри педагогіки та психології, Харківський національний університет внутрішніх справ, пр. Льва Ландау, 27, м. Харків, 61080, e-mail: Natasham69@ukr.net, https://orcid.org/0000-0002-0716-9736

Пашко Наталія Олександрівка аспірант кафедри педагогіки та психології, Харківський національний університет внутрішніх справ, пр. Льва Ландау, 27, м. Харків, 61080, e-mail: natalya@.pashko@gmail.com, https://orcid.org/0000-0002-2288-1537

\title{
ОСОБЛИВОСТІ ПСИХОЛОГІЧНОЇ ГОТОВНОСТІ У ПРОФЕСІЙНІЙ ДІЯЛЬНОСТІ
}

Анотація. У статті досліджуються особливості формування психологічної готовності до професійної діяльності. Проаналізовано трактування сутності категорії психологічної готовності до професійної діяльності через призму міжнародних та вітчизняних досліджень. Розглянуто структуру психологічної готовності у професійній діяльності. Теоретично проаналізовано різні наукові праці та підходи щодо визначення психологічної готовності та іï структури. Визначено предмет, об'єкт та психологічної готовності у професійній діяльності. У статті представлена структура психологічної готовності до професійної діяльності у різних професіях. Встановлено, що готовність до професійної діяльності $€$ важливою стороною становлення та саморозвитку впродовж усього життя. Визначено, що існує два ключових значення поняття «готовність до професійної діяльності» такі як, позитивне ставлення, маршрут, згода на ту чи іншу діяльність та умова, що дозволяє людині ефективно виконувати діяльність. Встановлено, що існують різні підходи до вивчення готовності до професійної діяльності: функціональний, особистісний та особистісно-діяльнісний підхід.

Мета статті полягає в упорядкуванні існуючих наукових праць, підходів, які досліджують психологічну готовність слідчих у контексті професійної діяльності та визначенні основної структури психологічної готовності та іiі складових.

Проблема психологічної готовності особистості до діяльності широко висвітлена у науковій літературі. Дослідниками напрацьовано значний за обсягом теоретичний і практичний матеріал, обгрунтовано кілька різних підходів до визначення поняття готовності, iї структури, умов розвитку, особливостей функціонування. За результатами вивчення наукової літератури уточнено визначення психологічної готовності до професійної діяльності. 
Практична значущість статті визначається інтеграцією теоретичних знань iз можливістю їх застосування на практиці в межах підходу, побудованого на активізації самопроцесів особистості як суб'єктів професійної діяльності.

Ключові слова: готовність, психологічна готовність, професійна діяльність, структура психологічної готовності.

Miloradova Nataliia Eduardivna Doctor of Psychological Sciences, Associate Professor, Professor ol of Pedagogy and Psychology, Kharkiv National University of Internal Affairs, Lva Landau, 27, Kharkiv, 61080, e-mail: Natasham69@ukr.net, https://orcid.org/0000-0002-0716-9736

Pashko Nataliia Oleksandrivna Postgraduate student of the Department of Pedagogy and Psychology, Kharkiv National University of Internal Affairs, Lva Landau, 27, Kharkiv, 61080, e-mail: natalya@.pashko@gmail.com, https://orcid.org/0000-0002-2288-1537

\section{FEATURES OF PSYCHOLOGICAL READYNESS IN PROFESSIONAL ACTIVITY}

Abstract. The paper studies the features of the formation of psychological readiness for professional activity. The interpretation of the essence of the category of psychological readiness for professional activity through the prism of international and domestic research is analyzed. The structure of psychological readiness in professional activity is considered. Theoretically, various scientific works and approaches to determining psychological readiness and its structure are analyzed. The subject, object and psychological readiness in professional activity are defined. The article presents the structure of psychological readiness for professional activity in different professions. It is established that readiness for professional activity is an important aspect of formation and self-development throughout life. It is determined that there are two key meanings of the concept of "readiness for professional activity" such as a positive attitude, route, consent to a particular activity and the condition that allows a person to perform effectively. It is established that there are different approaches to the study of readiness for professional activity: functional, personal and personal-activity approach.

The purpose of the article is determined in the organization of existing scientific papers, approaches that explore psychological readiness in the context of professional activity and determine the basic structure of readiness and its components.

The problem of psychological readiness of the individual for activity is widely covered in the scientific literature. Researchers have developed a significant amount of theoretical and practical material, substantiated several different approaches to defining the concept of readiness, its structure, development conditions, features of functioning. According to the results of studying the scientific literature, the 
definition of psychological readiness for professional activity has been clarified.

The practical significance of the article is determined by the integration of theoretical knowledge with the possibility of their application in practice within the approach based on the activation of self-processes of the individual as a subject of professional activity.

Keywords: readiness, psychological readiness, professional activity, structure of psychological readiness.

Постановка проблеми. Актуальною науковою проблемою є необхідність розвитку психологічної готовності майбутніх спеціалістів. Причини цього можуть бути пов'язані з тим, що майбутні спеціалісти повинні бути залучені до жорсткої конкуренції за вакансії та напрями діяльності, володіти сучасними інформаційно-комунікаційними засобами, тобто мати психологічну готовність до професійної діяльності. Процес перетворення системи професійної освіти супроводжується підвищенням вимог до молодих спеціалістів - випускників. Велика увага приділяється готовності майбутніх спеціалістів до успішного вирішення професійних завдань. Невідповідність професійних очікувань випускника закладу вищої освіти як спеціаліста, здатного вирішувати виробничі завдання, та рівня його професійної готовності до цього є одним із важливих аспектів в процесі формування психологічної готовності до професійної діяльності.

У психологічних соціологічних, педагогічних дослідженнях поняття «Готовність» вживається в контексті достатньо різнобічного спектра іiі психологічних проявів: готовність до ризику, діяльності, праці, мотивації, вибору професії, професійної діяльності, політичної діяльності, педагогічної діяльності, бойової діяльності тощо. Широкий огляд характеристик у розгляді поняття психологічної готовності свідчить про складність, динамічність і багатогранність функціонування цього феномена, котрий має прояв в житті особистості [1]. Теоретичний та практичний аналіз стану вивченості проблеми готовності, варто здійснювати у широкому психологічному контексті 3 урахуванням усіх характеристик, тому актуальним $є$ дослідження особливостей формування психологічної готовності до професійної діяльності.

Аналіз останніх досліджень і публікацій. Тематику психологічної готовності до професійної діяльності досліджує значна кількість науковців. Зокрема, наукові праці С. М. Іванова, К. М Гуревич, С. А. Климов, Кузьмина Н. В., Щербаков А. И., Вірна Ж. П., Смирнова Є. Е. , Моляко В. О., Линенко А. Ф., присвячені аналізу деяких аспектів та особливостей формування психологічної готовності до професійної діяльності, які вплинули на успішне працевлаштування та ефективне вирішення професійних завдань.

Мета статті. Мета роботи полягає в упорядкуванні існуючих наукових праць, підходів, які досліджують психологічну готовність слідчих у контексті професійної діяльності та визначенні основних структур психологічної готовності та їі складових. Для досягнення мети визначено такі завдання: 
визначити сутність та характерні ознаки психологічної готовності у контексті професійної діяльності; проаналізувати основну структуру та складові психологічної готовності у професійній діяльності. При проведенні дослідження були використані загальнонаукові й спеціальні методи дослідження, зокрема аналіз і синтез, порівняння, узагальнення, системноструктурний аналіз.

Виклад основного матеріалу. Проблематика розгляду психологічної готовності у різних професійних сферах $є$ предметом досліджень багатьох науковців.

Становлення тематики психологічних досліджень відбувалося у декілька етапів. Науковці вивчають готовність з середини XIX ст. завдяки дослідженню психічних процесів людини. На початку XX ст., внаслідок проведення інтенсивних досліджень нейрофізіологічних механізмів, регуляції i саморегуляції поведінки особистості, дослідники розглядають готовність як феномен, котрий взаємопов'язаний із стійкістю особистості до зовнішнього $\mathrm{i}$ внутрішнього впливів. Від середини XX ст. психологічну готовність науковці досліджують в контексті теорії діяльності і взаємопов'язують іiї з емоційновольовим й інтелектуальним потенціалом особистості відносно відповідної категорії діяльності та визначають як якісний показник саморегуляції фахівця на різних рівнях перебігу процесів таких як: психологічному, фізіологічному, соціальному [15].

Вперше термін «психологічна готовність до діяльності» було введено в психологічний обіг в 1976 році білоруськими дослідниками М. І. Дяченком і Л. А. Кандибовичем. Науковці досліджували структуру психологічної готовності у різноманітних професійних напрямках. Наприклад, Л. В. Кондрашова у своїх наукових працях зазначає, що психологічна готовність визначається як встановлення суті властивостей і стану особистості [7].

Досліджуючи професійну діяльність слідчого О. М. Пасько розглядала психологічну готовність як інтегральний стан, який визначає його здатність до врахування структури психіки у своїй діяльності [11].

Психологічну готовність А. Є. Томілова розуміє як тривалий або короткочасний стан людини, котрий скерований на свідоме або підсвідоме програвання майбутньої ситуації [17].

П. П. Горностаєм під терміном «професійна готовність» розглядав, як загальну готовність особистості до професійної діяльності (як психологічну, так і фізичну), котра за терміном часу може бути як тривалою (професійна підготовленість), так і короткочасною [2].

Структуру психологічної готовності особистості до різних видів правоохоронної діяльності досліджували О. М. Бандурка, В. Л. Васильєв, Л. І. Казиміренко, О. М. Пасько, О.В. Тимченко, М.І. Томчук, І.М. Чорна та ін. Цільмак О.M., Охрименко I.M., Барко B.I., I.B. Платонов розглядає психологічну готовність особистості до правоохоронної діяльності як складну, інтегральну властивість людини, яка 
описує ऑї придатність до реалізації загальних вимог професійної правоохоронної діяльності [13].

Н. Г. Іванової трактує термін «психологічна готовність» як психічний стан, котрий з'являється в результаті професійної підготовки і знаходиться в залежності від мотивів, емоційно-вольових процесів, інтелектуальних можливостей, рівня розвитку загальних, спеціальних та творчих здібностей особистості. Психічний стан Н. Г. Іванової визначає як системну характеристику психічної діяльності особистості, на котру здійснюють вплив специфічні ознаки психічного відображення ситуації, в котрій знаходиться особистість. Дослідниця зазначає, що психологічна готовність створюється та розвивається поступово при переході психічних станів із нестійких до поточних, а далі i до перманентних. Отже, психологічна готовність до професійної діяльності визначається як основа психологічної готовності до реалізації відповідних завдань [4].

Психологічну готовність до діяльності вважає психічним станом також і дослідниця В.О. Семиченко. Структура психологічної готовності, згідно 3 твердженням В.О. Семиченко $\epsilon$ наступною: 3 операційної готовності до термінової активізації особистості; функціональної готовності - усвідомлення особистістю власних цілей, оцінки поточних постулатів, встановлення найбільш ймовірних засобів дії; особистісної готовності - пролонгованої високої активності особистості, розподілу вольових, мотиваційних, інтелектуальних зусиль, оцінки ймовірності здобуття життєвих успіхів завдяки професійній діяльності [14].

У літературі велика увага приділяється поняттю «готовність до професійної діяльності». Професійна діяльність - це суспільно значуща діяльність, яка потребує спеціальних знань, умінь і професійних якостей (Е.Ф. Зехер). Важливою для ефективної професійної діяльності вважається «професійна готовність» (М.І. Дяченко, В.С. Мерлін, В.Н. Мясищев, К.К. Платонов та ін.). Професійну готовність поділяють на практичну та теоретичну. Практична готовність передбачає наявність певних особистісних якостей, знань, умінь і навичок, які дозволяють виконувати професійні цілі, а також функціональні обов'язки.

Що стосується теоретичної готовності, то вона включає певні знання про саму професію, глибокі професійні знання, а також здатність людини до виконання обраної професії. Говорячи про теоретичну підготовленість, дослідники відзначають вміння спостерігати за процесами, що відбуваються, аналізувати їх перебіг, визначати їх складові та встановлювати взаємні зв'язки між ними, осмислювати кожну частину будь-якого процесу та знаходити притаманні їм закономірності.

Підводячи підсумок, теоретична підготовленість тісно пов'язана 3 навичками прогнозування, які включають вміння передбачити результат будьякої дії до іï виконання, що дає змогу передбачити розвиток професійного процесу. Практичний i теоретичний види готовності тісно взаємопов'язані i 
включають здатність мислити, планувати, організовувати та досягати бажаних цілей.

Таким чином, існує два ключових значення поняття «готовність до професійної діяльності»:

а) позитивне ставлення, маршрут, згода на ту чи іншу діяльність;

б) умова, що дозволяє людині ефективно виконувати діяльність.

Аналіз наукової літератури 3 проблеми готовності до професійної діяльності показав, що існують різні підходи до вивчення готовності до професійної діяльності:

1) функціональний підхід, де готовність є особливим психологічним станом (Е. П. Ільїн, А. С. Прангішвілі, А. С. Пуні, Д. Н. Узнадзе та ін.);

2) особистісний підхід, що трактує готовність як стійку характеристику особистості, що виражається в прояві індивідуальних якостей, що сприяють ефективному здійсненню діяльності. (Кузьміна Н.В., А.Н. Леонтьєв, В.А. Сластенін та ін.);

3) особистісно-діяльнісний підхід, коли готовність розглядається як поєднання властивостей особистості та готовності людини до виконання необхідних дій і виражається в цілісному прояві всіх сторін особистості, що дозволяє їй ефективно виконувати свої функції (М.I. Дяченко, I. А. Зимня та ін.) $[18]$.

У своїх наукових роботах 3 психології діяльності в специфічних умовах В. Барко досліджує психологічну готовність до управлінської діяльності як «довготривалий психічний стан, який структурно формується 3 комплексу суб'єктивних i об'єктивних компонентів i включає мотиви, інтереси, темпераментні і характерологічні особливості, здібності, знання й уміння, які в сукупності асекурують здатність до успішної професійної діяльності».

B.I. Барко розглядав термін психологічної готовності у діяльності керівника органу внутрішніх справ до управлінської діяльності та трактував дане поняття як довготривалий психічний стан, котрий структурно формується з комплексу суб'єктивних і об'єктивних компонентів і містить в собі мотиви, інтереси, здібності, темпераментні й характерологічні особливості, знання і уміння, які в сукупності асекурують здатність до успішної професійної діяльності [5].

В. А. Молотаєм проаналізував головний комплекс психологічної готовності військово-службовців Внутрішніх військ МВС України до службово-бойової діяльності та встановив наступне: 1) стійкість та адаптивна урегульованість дій; 2) усвідомлення військово-службовцем соціального та особистісного сенсу участі у службово-бойовій діяльності; 3) адекватність дій правоохоронним нормам і умовам службово-бойових ситуацій; 4) своєчасність і доцільність оперативних службово-бойових дій [9].

О. С. Тарновською було проведено аналіз різних підходів стосовно трактування психологічної готовності до діяльності (на прикладі педагогічної 
діяльності), i запропонувала розуміти дане поняття як інтегративне формування, що базується на трьох взаємозумовлених і взаємозалежних підструктур, таких як: 1) емоційна (налаштування на розв'язання професійних завдань, формування впевненості у собі як у професіоналі своєї діяльності та стану задоволеності професійною діяльністю тощо); 2) функціональна, до складу котрої входять наступні складові компоненти: мотиваційний (мотиви вибору професійної діяльності і спеціальності, орієнтація на ії цінності тощо); когнітивний (знання спеціальних дисциплін); операційний (наявність вмінь і навичок, потрібних для розв'язання професійних завдань, модулювання своєї професійної діяльності); 3) особистісна (професійно необхідні якості особистості: вольові, моральні та ін.)

У своєму досліджені О. В. Платонов виокремив структуру готовності за трьома взаємопов'язаними компонентами: 1) загальна професійна (визначається рівнем розвитку професійних знань, навичок і вмінь, котрі потрібні молодому фахівцю на початковому етапі професійної діяльності та сформованістю його психічних пізнавальних процесів, які протегують формуванню результативності діяльності працівника правоохоронних органів); 2) мотиваційна готовність (визначається складною системою мотивів, які направляють, посилюють та зумовлюють активність особистості стосовно зазначеної діяльності); 3) емоційно-вольова готовність (визначається вмінням особистості до свідомої регуляції власної поведінки, дій у будь-яких ситуаціях, у відповідній професійній діяльності у відповідності до законів і вимог суспільства) [12].

У структурі психологічної готовності курсантів до льотної діяльності Л. О. Матохнюк, виокремлює мотиваційний, когнітивний, операційний, емоційно-вольовий компоненти та професійно-важливі якості особистості військового пілота [5]. Розглядаючи трудову діяльність відповідно до ії контексту i відповідних завдань, які вирішуються суб'єктом трудової діяльності, низка науковців класифікують психологічну готовність на короткотривалу (ситуативну), котра детермінується певними психічними станами, і відносно сталу, котра окреслюється стабільними характерними ознаками особистості. Дослідники визначають довготривалу готовність як стійкий комплекс особистісних якостей, потрібних для успішної діяльності в різноманітних ситуаціях [1].

На думку Л. О. Матохнюк психологічна готовність включає систему знань, потрібних для успішної діяльності (знання професійних обов'язків, функцій, оцінка їхньої суспільної значущості, знання методів, мотивація, зацікавленість, розуміння засобів розв'язання завдань, усвідомлення персональних можливостей, специфічних ознак та ймовірних змін у службовій діяльності тощо).

Аналізуючи діяльність працівників поліції та їх психологічну готовність до використання вогнепально-силового впливу I. Ю. Горелов визначає як комплексне багатокомпонентне формування, що містить наступні складові: 
1) потрібний рівень професійної підготовки; 2) мотиваційні компоненти (відданість фаховій професійній діяльності, необхідність у самовдосконаленні); 3) специфічні ознаки особистості, які встановлюють вправність ефективно діяти в екстремальних ситуаціях (високі здібності саморегуляції психічного стану; комунікативні особливості; оптимальні рівні особистісної та ситуативної тривожності; інтелектуальні, емоційно-вольові якості тощо) [13].

В таблиці 1. відображені погляди науковців стосовно загальної готовності до професійної діяльності.

Таблиия 1.

\section{Погляди науковців стосовно загальної готовності}

до професійної діяльності

\begin{tabular}{|c|c|c|}
\hline \multicolumn{3}{|c|}{ Компоненти в структурі загальної готовності до професійної діяльності } \\
\hline $\begin{array}{l}\text { М.I. Дяченко; Л. А. Кандибович } \\
\text { [3] }\end{array}$ & $\begin{array}{l}\text { В.А. Сластеніна, } \\
\text { Л.С. Подимова [16] }\end{array}$ & О.М. Краснорядцева [8] \\
\hline 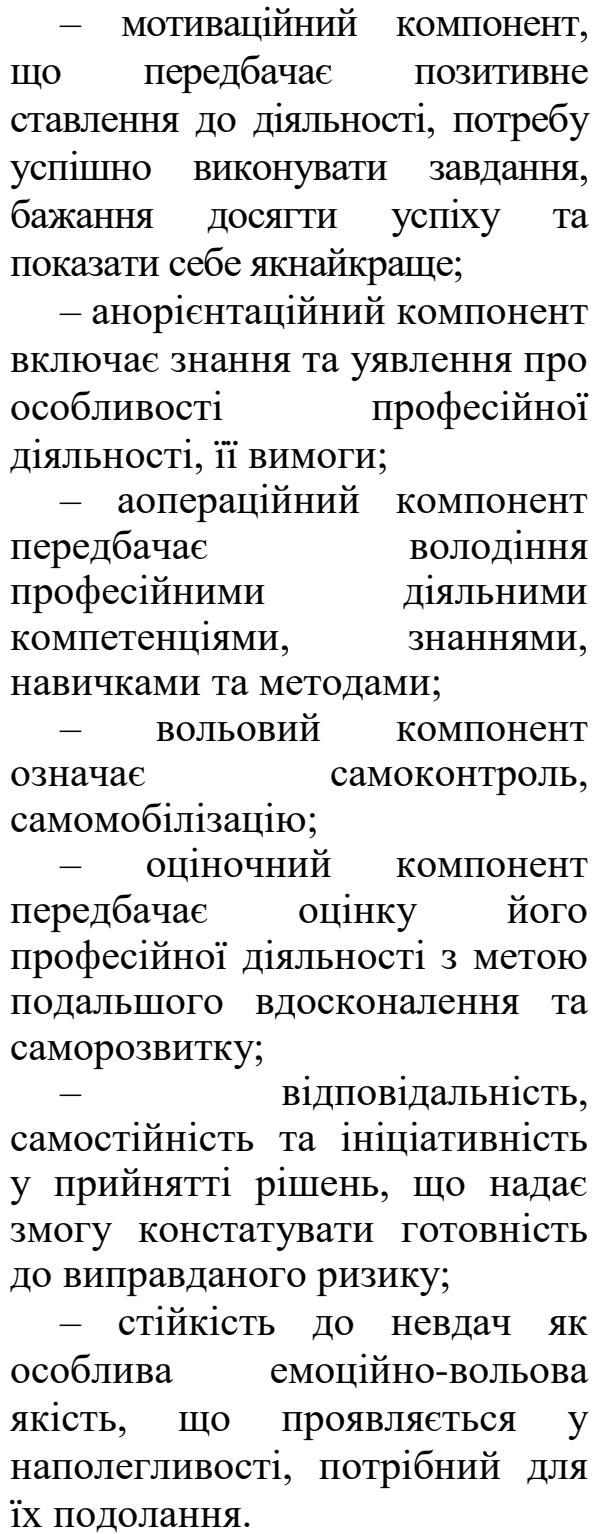 & 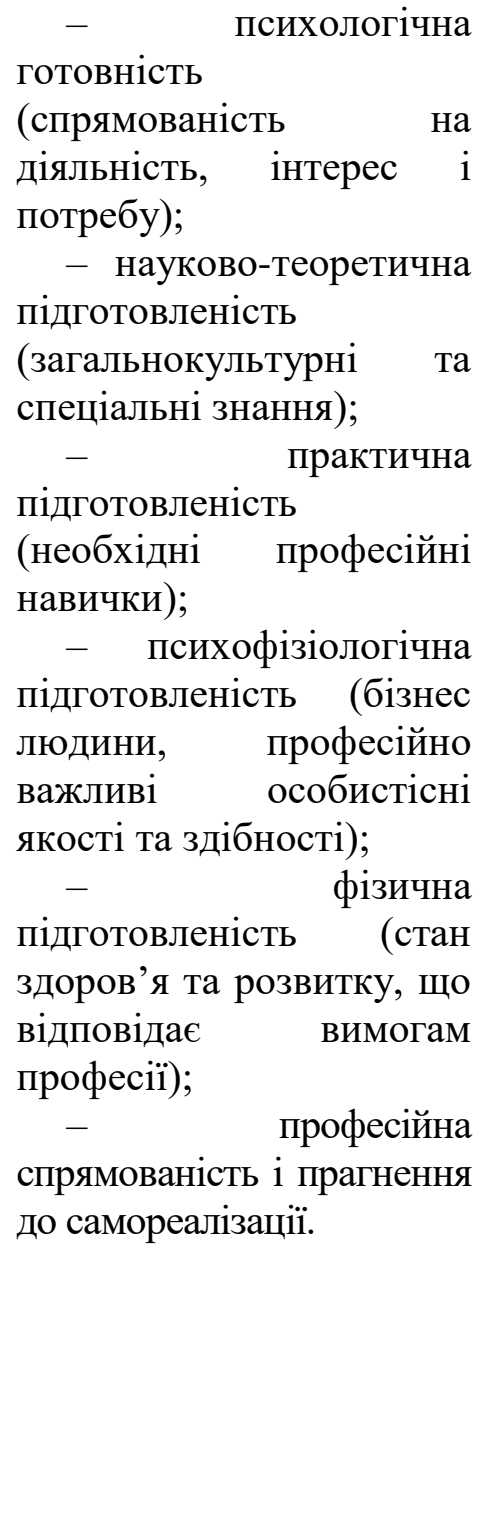 & $\begin{array}{l}-\quad \text { ставлення як } \\
\text { відображення минулого } \\
\text { досвіду на поточну } \\
\text { ситуацію; } \\
\quad-\quad \text { мотиваційна } \\
\text { готовність усвідомити } \\
\text { сенс і цінність того, що } \\
\text { робить людина; } \\
-\quad \text { професійно- } \\
\text { особистісна готовність } \\
\text { до самоактуалізації } \\
\text { через процес } \\
\text { персоналізації. }\end{array}$ \\
\hline
\end{tabular}

Примітки: сформовано на основі джерел: [3; 8; 16]. 
Підводячи підсумок, можна зазначити, що немає єдиної точки зору щодо структурного складу готовності до професійної діяльності, що ускладнює процес діагностики. На формування готовності впливають як зовнішні, так і внутрішні фактори: задатки, здібності, емоційно-мотиваційна готовність до праці, рівень підготовки, зовнішні умови функціонування тощо.

Висновок. Проаналізувавши різні погляди вітчизняних i закордонних науковців можна підсумувати, що структура психологічної готовність включає в себе комплекс професійних знань, умінь і навичок; обов'язкові риси особистості, які мають бути у працівника: мотивація, розвинуті аналітичні здібності, вміння діяти та виконувати завдання відповідно до специфіки професійної діяльності, готовність до змін, стресостійкість, цілеспрямованість, висока організованість і послідовність, ініціативність. Таким чином під психологічною готовністю особистості ми розуміємо певний психічний стан, який виникає внаслідок виконання професійної діяльності та має структуру, яка складається з когнітивного, особистістного та мотиваційного компонентів.

Практичне значення проведеного дослідження полягає в тому, що висновки та рекомендації, розроблені автором та запропоновані в статті, можуть бути використані для: застосування теоретичних знань про психологічну готовність на практиці в межах підходу, побудованого на активізації самопроцесів особистості як суб'єктів професійної діяльності.

\section{Лimepamypa:}

1. Байбекова Н. Формування готовності майбутніх психологів до консультативної роботи у вищих педагогічних навчальних закладах. Збірник наукових прачь Уманського державного педагогічного університету. 2013. Ч. 3. С. 22- 27.

2. Горелов І. Ю. Психологічна готовність працівників ОВС до застосування вогнепально-силового впливу: автореф. дис... канд. психол. наук: спец. 19.00.09 / І. Ю. Горелов. Х., 2008. 19 с.

3. Дьяченко М. И., Кандыбович Л. А. Психологические проблемы готовности к деятельности. Минск: Изд-во БГУ, 1976. 173 с.

4. Іванова Н. Г. Формування психологічної готовності правоохоронців до діяльності в екстремальних умовах. Вісник Національного університету оборони України. 3б-к наук. пращь. Київ: НУОУ, 2014. Вип. 6 (43). С. 294-299.

5. Керницький О. М. Теоретичний аналіз проблеми формування пси- хологічної готовності курсантів-льотчиків до військово-професійної діяль- ності. Військова освіта: [зб. наук. пр.]. 2003. № 14. С. 50-59.

6. Кокун О.М. Зміст та структура психологічної готовності фахівців до екстремальних видів діяльності. Проблеми екстремальної та кризової психології. Збірник наукових праць. Харків.: УЦЗУ, 2010. Вип. 7. С. 182 - 190.

7. Кондрашова Л. В. Моральна психологічна готовність студента до вчительської діяльності, Київ, "Вища школа", 1987, 218 с.

8. Краснорядцева О.М. Чувствительность к проблемам: от исследовательских процедур к диагностике потенциала самореализации личности. Методология и история психологии, 2009, т. 4, вып. 4. С. 73-81.

9. Молотай В. А. Формування психологічної готовності військовос- лужбовців внутрішніх військ МВС України до діяльності по охороні громадського порядку: автореф. дис... канд. психол. наук: спец. 19.00.09 / В. А. Молотай. Хмельницкий, 2006. 20 с. 
10. Моляко В. О. Психологічна готовність до творчої праці. Київ, «Знання» 1989.

11. Пасько О. М. кандидат юридичних наук, доцент, доцент кафедри криміналістики та психології Одеського державного університету внутрішніх справ, м. Одеса ORCID: https://orcid.org/0000-0001-9555-1101 Структурні компоненти готовності слідчого до професійної діяльності.

12. Платонов І. В. Структура психологічної готовності особистості до правоохоронної діяльності. Психологія. К.: НПУ ім. М. П. Драгоманова, 2000. Вип. 11. С. 320-326.

13. Психология высшей школы [Текст] : научное издание / М. И. Дьяченко, Л. А. Кандыбович. 2-е изд., перераб. и доп. Минск : Изд-во БГУ, 1981. 383 с.

14. Семиченко В. А. Проблемы мотивации поведения и деятельности человека: модульный курс, психологи. Модуль «Направленность» : лекции, практические занятия, задания для самостоятельной работы для преподавателей и студентов. Киев : Миллениум, 2004. 521 с.

15. Сімко Р. Т. Поняття готовності до професійної діяльності на сучасному етапі розвитку психологічної науки. Проблеми сучасної психологї̈: зб. наук. пращь К-ПНУ імені Івана Огієнка, Інституту психології ім. Г. С. Костюка НАПН Украӥни. Київ : Інститут психології ім. С. Костюка НАПН України, 2011. Вип. 13. С. 415-425.

16. Сластенина В.А., Подымова Л.С. Педагогика: инновационная деятельность. М .: Магистр, 1997. 224 с.

17. Томилова А.Е. Психологическая подготовка и боевая готовность сотрудников ОВД к действиям в экстремальных ситуациях. Психопедагогика в правоохранительных органах. 1998. №1(7). C.54-57.

18. Seryapina Y.S. The concept of "readiness for pedagogical activity": motivational readiness, psychological readiness, readiness to innovative activity. Вестник Южно-Уральского государственного университета. Серия: Образование. Педагогические науки, 2018, vol. 10, № 4, pp. 77-86.

\section{References:}

1. Baibekova, N. (2013). Formuvannia hotovnosti maibutnikh psykholohiv do konsultatyvnoi roboty u vyshchykh pedahohichnykh navchalnykh zakladakh. [Formation of readiness of future psychologists for consultative work in higher pedagogical educational institutions]. Zbirnyk naukovykh prats Umanskoho derzhavnoho pedahohichnoho universytetu. Ch. 3. pp. 22-27 [in Ukrainian].

2. Horielov, I.Yu. (2008). Psykholohichna hotovnist pratsivnykiv OVS do zastosuvannia vohnepalno-sylovoho vplyvu. [Psychological readiness of police officers to use fire and power influence]: avtoref. dys... kand. psykhol. nauk: spets. 19.00.09/I. Yu. Horielov. Kh. [in Ukrainian].

3. Diachenko, M.I., Kandybovych, L.A. (1976). Psykholohichni problemy hotovnosti do diialnosti. [Psychological problems of readiness for activity]. Minsk: Vyd-vo BDU. [in Russian].

4. Ivanova, N.H. (2014). Formuvannia psykholohichnoi hotovnosti pravookhorontsiv do diialnosti $\mathrm{v}$ ekstremalnykh umovakh. [Formation of psychological readiness of law enforcement officers to work in extreme conditions]. Visnyk Natsionalnoho universytetu oborony Ukrainy. Zbdo nauk. prats. Kyiv: NUOU. Vyp. 6 (43). pp. 294-299 [in Ukrainian].

5. Kernytskyi, O.M. (2003). Teoretychnyi analiz problemy formuvannia psykholohichnoi hotovnosti kursantiv-lotchykiv do viiskovo-profesiinoi diialnosti. [Theoretical analysis of the problem of formation of psychological readiness of cadet pilots for military-professional activity]. Viiskova osvita: [Zb. nauk. pr.]. № 14. pp. 50-59 [in Ukrainian].

6. Kokun, O.M. (2010). Zmist ta struktura psykholohichnoi hotovnosti fakhivtsiv do ekstremalnykh vydiv diialnosti. [Content and structure of psychological readiness of specialists for extreme activities]. Problemy ekstremalnoi ta kryzovoi psykholohii. Zbirnyk naukovykh prats. Kharkiv: UTsZU. Vip. 7. pp. 182 - 190 [in Ukrainian].

7. Kondrashova, L.V. (1987). Moralna psykholohichna hotovnist studenta do uchytelskoi diialnosti. [Moral psychological readiness of students for teaching]. Kyiv, "Vyshcha shkola", [in Ukrainian]. 
8. Krasnoriadtseva, O.M. (2009). Chutlyvist do problem: vid doslidnytskykh protsedur do diahnostyky potentsialu samorealizatsii osobystosti. [Sensitivity to problems: from research procedures to diagnosing the potential of self-realization of the individual]. Metodolohiia ta istoriia psykholohii, t. 4, vyp. 4. pp. 73-81 [in Russian].

9. Molotai, V.A. (2006). Formuvannia psykholohichnoi hotovnosti viiskovos- luzhbovtsiv vnutrishnikh viisk MVS Ukrainy do diialnosti z okhorony hromadskoho poriadku. [Formation of psychological readiness of servicemen of the internal troops of the Ministry of Internal Affairs of Ukraine to the activities of public order protection]: avtoref. dys... kand. psykhol. nauk: spets. 19.00.09/V. A. Molotai. Khmelnytskyi. [in Ukrainian].

10. Moliako, V.O. (1989). Psykholohichna hotovnist do tvorchoi pratsi. [Psychological readiness for creative work]. Kyiv, "Znannia".

11. Pasko, O.M. (2021). kandydat yurydychnykh nauk, dotsent, dotsent kafedry kryminalistyky ta psykholohii Odeskoho derzhavnoho universytetu vnutrishnikh sprav, m. Odesa ORCID: https://orcid.org/0000-0001-9555-1101 Strukturni komponenty hotovnosti slidchoho do profesiinoi diialnosti. [Structural components of the investigator's readiness for professional activities]. [in Ukrainian].

12. Platonov, I.V. (2000). Struktura psykholohichnoi hotovnosti osobystosti do pravookhoronnoi diialnosti. [The structure of psychological readiness of the individual to law enforcement]. Psykholohiia. Kyiv: NPU im. M. P. Drahomanova, Vyp. 11.pp. 320-326 [in Ukrainian].

13. Diachenko, M.I., Kandybovych, L.A. (1981). Psykholohiia vyshchoi shkoly. [Psychology of higher school]. Minsk: Vyd-vo BDU. [in Russian].

14. Semychenko, V.A. (2004). Problemy motyvatsii povedinky ta diialnosti liudyny: modulnyi kurs, psykholohy. [Problems of motivation of human behavior and activity: a modular course, psychologists]. Modul «Spriamovanist»: lektsii, praktychni zaniattia, zavdannia dlia samostiinoi roboty dlia vykladachiv ta studentiv. Kyiv: Milenium. [in Ukrainian].

15. Simko, R.T. (2011). Poniattia hotovnosti do profesiinoi diialnosti na suchasnomu etapi rozvytku psykholohichnoi nauky. [The concept of readiness for professional activity at the present stage of development of psychological science]. Problemy suchasnoi psykholohii: zb. nauk. prats K-PNU imeni Ivana Ohiienka, Instytutu psykholohii im. H. S. Kostiuka NAPN Ukrainy. Kyiv : Instytut psykholohii im. S. Kostiuka NAPN Ukrainy. Vip. 13. pp. 415-425 [in Ukrainian].

16. Slastenina, V.A., Podymova, L.S. (1997). Pedahohika: innovatsiina diialnist. [Pedagogy: innovative activity]. Moskov: Mahistr. [in Russian].

17. Tomilova, A.Ie. (1998). Psykholohichna pidhotovka ta boiova hotovnist spivrobitnykiv OVS do dii v ekstremalnykh sytuatsiiakh. [Psychological training and combat readiness of police officers to act in extreme situations]. Psykhopedahohika u pravookhoronnykh orhanakh. №1(7). pp.54-57 [in Russian].

18. Seryapina, Y.S. (2018). The concept of "readiness for pedagogical activity": motivational readiness, psychological readiness, readiness to innovative activity. [The concept of "readiness for pedagogical activity": motivational readiness, psychological readiness, readiness to innovative activity]. Visnyk Pivdenno-Uralskoho derzhavnoho universytetu. Seriia: Osvita. Pedahohichni nauky, vol. 10, №4, pp. 77-86 [in English]. 